\title{
PENGEMBANGAN ANIMASI KETERAMPILAN BERBICARA BAHASA INGGRIS DENGAN MULTIMEDIA DEVELOPMENT LIFE CYCLE GODFREY
}

\author{
Nisa’ul Hafidhoh*1, Liya Umaroh ${ }^{2}$, Sugiyanto ${ }^{3}$ \\ 1,2,3 Universitas Dian Nuswantoro \\ Email: ${ }^{1}$ nisa@dsn.dinus.ac.id, ${ }^{2}$ liya.umaroh@dsn.dinus.ac.id, ${ }^{3}$ sugiyanto@dsn.dinus.ac.id \\ *Penulis Korespondensi
}

(Naskah masuk: 21 Maret 2019, diterima untuk diterbitkan: 10 Februari 2020)

\begin{abstract}
Abstrak
Persaingan global menuntut kemampuan bahasa Inggris dalam komunikasi. Akan tetapi, kecakapan berbahasa Inggris orang Indonesia tergolong rendah yaitu sebesar 51,58 di bawah Filipina $(61,84)$ dan Malaysia $(59,32)$. Survey menunjukkan keterampilan berbicara bahasa Inggris dalam masyarakat lebih rendah dibanding keterampilan membaca dan mendengar. Keterampilan berbicara dapat dilatih melalui aspek audio untuk mendengar kalimat bahasa Inggris dan aspek visual untuk melihat kalimat bahasa Inggris. Oleh karena itu dapat digunakan animasi sebagai salah satu media pembelajaran audiovisual. Dalam penelitian ini dikembangkan animasi keterampilan berbicara bahasa Inggris dengan topik wawancara kerja untuk membantu dalam persaingan lapangan kerja di era global. Pengembangan animasi menggunakan metode Multimedia Development Life Cycle Godfrey yang terdiri dari tahap problem definition, genre and character, location and interface, plotting, scripting, production and testing serta use. Pengujian beta digunakan terhadap animasi yang telah dikembangkan untuk mendapatkan masukan dari pengguna. Sedangkan untuk evaluasi keterampilan berbicara bahasa Inggris digunakan penelitian eksperimen dengan dua kelas kontrol dan dua kelas eksperimen dari mahasiswa semester I. Nilai yang signifikan ditunjukkan pada kelas eksperimen setelah memanfaatkan animasi dalam pembelajaran.
\end{abstract}

Kata kunci: animasi, bahasa inggris, keterampilan bicara, multimedia development life cycle godfrey

\section{ANIMATION DEVELOPMENT OF ENGLISH SPEAKING SKILLS USING GODFREY MULTIMEDIA DEVELOPMENT LIFE CYCLE}

\begin{abstract}
Global competition requires English language skills in communication. However, English proficiency of Indonesian is relatively low at 51.58 below the Philippines (61.84) and Malaysia (59.32). Survey shows that English speaking skills in the community are lower than reading and listening skills. Speaking skills can be trained through audio aspects to hear English sentences and visual aspects to see English sentences. Therefore animation can be used as one of the audiovisual learning media. In this study an animation of English speaking skills was developed with the topic of job interviews to assist in employment competition in the global era. Animation development uses Godfrey's Multimedia Development Life Cycle which consists of problem definition, genre and character, location and interface, plotting, scripting, production and testing also use stages. Beta testing is used in animations that have been developed to get feddback from users. As for evaluating English speaking skills, experimental research was used with two control classes and two experimental classes from first semester students. Significant values are shown in the experimental class after using animation in learning.
\end{abstract}

Keywords: animation, english, speaking skill, godfrey multimedia development life cycle

\section{PENDAHULUAN}

Di era modern ini, persaingan global kian meningkat di Indonesia hingga menuntut kemampuan Bahasa Inggris dalam komunikasi pada skala global. Kini kemampuan Bahasa Inggris telah banyak menjadi salah satu persyaratan dalam melamar pekerjaan, akan tetapi kecakapan berbahasa Inggris orang Indonesia masih rendah (Putri, 2018). Bahkan menurut hasil survey English First (EF) tahun 2018, indeks kecakapan Bahasa Inggris di Indonesia tergolong rendah yaitu sebesar 51,58 di bawah Filipina $(61,84)$ dan Malaysia $(59,32)$ (English First, 2018). Dari survey EF, keterampilan berbicara dalam bahasa Inggris masyarakat Indonesia lebih rendah 
dua level dibanding keterampilan membaca dan mendengar. Oleh karena itu perlu dikembangkan cara untuk meningkatkan keterampilan berbicara bahasa Inggris pada masyarakat.

Keterampilan berbicara dalam bahasa Inggris adalah kemampuan untuk mengungkapkan gagasan dalam komunikasi lisan menggunakan bahasa Inggris. Ada berbagai aspek yang dinilai dalam keterampilan berbicara dalam bahasa Inggris antara lain fluency (kelancaran berbicara), accuracy (kebenaran tata bahasa dan kosakata yang digunakan), clarity (kejelasan pronounciation), intonation (intonasi), volume, content (isi gagasan yang disampaikan) (Zaim,2013).

Keterampilan berbicara bahasa Inggris dapat dilihat dari kecakapan dalam melafalkan kalimat bahasa Inggris. Hal tersebut dapat dilatih dengan melihat kalimat bahasa Inggris untuk melatih aspek accuracy dan content. Selain itu, dengan mendengar cara pelafalan kalimat tersebut untuk melatih aspek fluency, clarity, intonation dan volume. Oleh karena itu perlu dilatih melalui aspek audio untuk mendengar kalimat bahasa Inggris dan aspek visual untuk melihat kalimat bahasa Inggris.

Salah satu media yang dapat membantu melatih keterampilan berbicara Bahasa Inggris adalah memanfaatkan animasi sebagai media pembelajaran audiovisual. Seperti dalam penelitian King, dkk (2014) yang menunjukkan perubahan signifikan dalam pemerolehan keterampilan bahasa Inggris dengan menggunakan multimedia pembelajaran. Oleh karena itu, pada penelitian ini dirancang animasi untuk mendukung keterampilan berbicara dalam bahasa Inggris. Untuk membantu dalam pengembangan animasi maka akan digunakan salah satu metodologi pengembangan multimedia.

\section{METODE PENELITIAN}

Metode pengembangan untuk animasi berbeda dengan metode pengembangan perangkat lunak. Berbagai metode pengembangan animasi yang merupakan salah satu bentuk multimedia telah banyak diusulkan antara lain Godfrey, VillamilMolina, Vaughan dan berbagai metode lain. Pada penelitian ini digunakan metode pengembangan multimedia Godfrey. Metode ini adalah turunan dari metode pengembangan perangkat lunak klasik yaitu Waterfall, sehingga disebut juga Multimedia Development Life Cycle (Godfrey, 1995). Tahapan pada metode pengembangan multimedia Godfrey dapat dilihat pada Gambar 1 yaitu problem definition, genre \& character, location \& interface, plotting, scripting, production \& testing dan use. Metode ini dipilih karena memiliki tahapan yang jelas, terstruktur dan mudah dipahami (Eryanti, Arta, \& Maria, 2018).

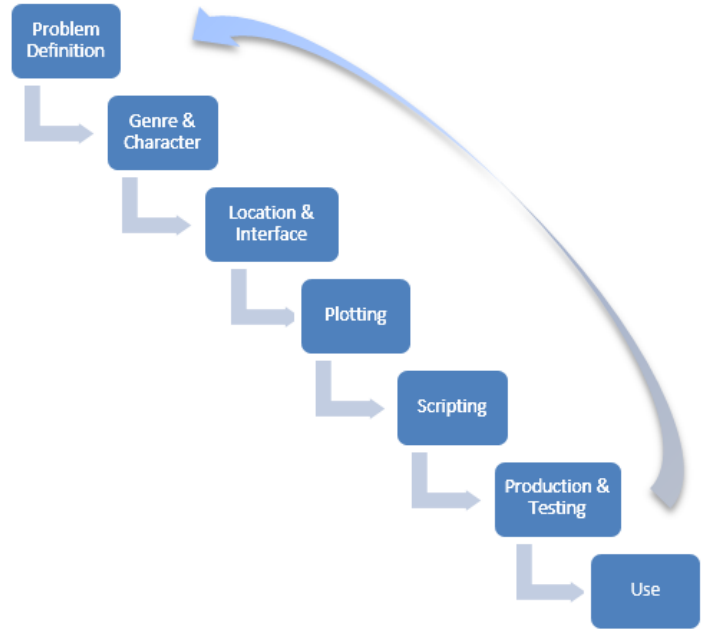

Gambar 1. Metode Pengembangan Multimedia Godfrey

Berdasarkan tahapan pada metode Godfrey, maka tahapan perancangan animasi keterampilan berbicara dalam berbahasa Inggris adalah sebagai berikut;

\section{Problem Definition}

Pada tahap definisi masalah dilakukan identifikasi target penonton serta kebutuhan mereka. Selain itu identifikasi ruang lingkup dan sumber daya juga perlu dilakukan untuk mengetahui kemampuan dalam membuat animasi.

\section{Genre \& Character}

Pada tahap ini ditentukan genre yang akan dibuat untuk animasi. Selain itu, pada tahap ini juga mulai dipilih dan dirancang karakter yang akan digunakan dalam animasi.

3. Location \& Interface

Penentuan lokasi serta gambaran antarmuka sebagai rancangan tata letak dan acuan sketsa animasi.

\section{4. $\quad$ Plotting}

Dari penentuan lokasi, selanjutnya disusun berbagai jalan cerita beserta aktivitas yang ada dalam sketsa animasi. Plotting dapat dirancang menggunakan storyboard untuk membantu dalam menggambarkan tiap bagian dalam alur cerita. Storyboard adalah rangkaian sketsa untuk menggambarkan urutan bagian dalam film (Ariyati \& Misriyati, 2016)

5. Scripting

Dalam tahap scripting didefinisikan semua dialog, aksi, adegan dalam animasi dengan lebih detil.

6. Production \& Testing

Berikutnya fase implementasi pada tahap produksi dan pengujian. Animasi memadukan unsur seni dan teknologi (Soenyoto, 2017). Pada tahap produksi dibutuhkan kolaborasi dari desainer karakter, desainer properti dan environtment, pembuat audio dan animator. Kerjasama mereka sangat dibutuhkan dalam 
menggabungkan setiap elemen media pada saat pembuatan animasi dengan menggunakan aplikasi pengembang animasi. Pengujian dilakukan secara bersama-sama antara tim pengembang animasi, narasumber Bahasa Inggris dan peserta.

7. Use

Tahap terakhir dari metode ini menjabarkan penggunaan animasi kepada peserta. Selain itu, animasi yang telah dihasilkan akan dibuat dalam bentuk video yang mudah digunakan dan didistribusikan. Animasi yang telah ditonton juga akan dievaluasi dan menjadi bahan masukan untuk pendefinisian masalah dan pengembangan berikutnya.

Tahap problem definition hingga scripting adalah fase analisis dan perancangan, sedangkan tahap production and testing serta use adalah fase implementasi dari hasil desain pada tahap sebelumnya (Binanto, 2013).

Untuk menguji hasil pemanfaatan animasi terhadap keterampilan berbicara bahasa Inggris digunakan penelitian eksperimen untuk mengetahui konsekuensi dari suatu perlakuan yang diberikan (Jaedun, 2011). Pengujian dilakukan dengan memberikan animasi dalam pembelajaran di kelas eksperimen, sedangkan kelas kontrol tidak diberikan animasi. Selanjutnya kedua kelas diberikan pre-test dan post-test.

\section{PERANCANGAN}

Pada bab ini dijabarkan fase perancangan pada metode Godfrey yang terdiri dari tahap problem definition hingga scripting. Perancangan animasi untuk meningkatkan keterampilan berbicara dalam berbahasa Inggris adalah sebagai berikut;

\subsection{Problem Definition}

Pada tahap ini didefinisikan masalah serta kebutuhan dalam perancangan animasi keterampilan berbicara dalam berbahasa Inggris. Hasil pada tahap ini antara lain :

1. Berdasarkan hasil studi lapangan terhadap mahasiswa semester I, kemampuan bahasa Inggris pada mahasiswa masih kurang, terutama keterampilan berbicara bahasa Inggris. Mahasiswa lebih mudah membaca kalimat bahasa Inggris dibanding melafalkannya.

2. Target yang dituju adalah mahasiswa yang selepas masa kuliah akan melamar pekerjaan. Oleh karena itu, ruang lingkup materi yang disampaikan dalam animasi tentang wawancara ketika melamar pekerjaan untuk menghadapi persaingan global.

3. Sumber daya yang diperlukan untuk merancang animasi adalah komputer, speaker dan program pendukung lainnya.

\subsection{Genre and Character}

Genre yang diangkat dalam animasi yang dirancang adalah simulasi. Animasi dirancang dengan meniru lokasi, suasana dan percakapan yang biasa terjadi saat melamar pekerjaan. Dengan simulasi kejadian sebenarnya saat wawancara kerja, peserta diajak merasakan pengalaman yang dekat dengan dunia nyata.

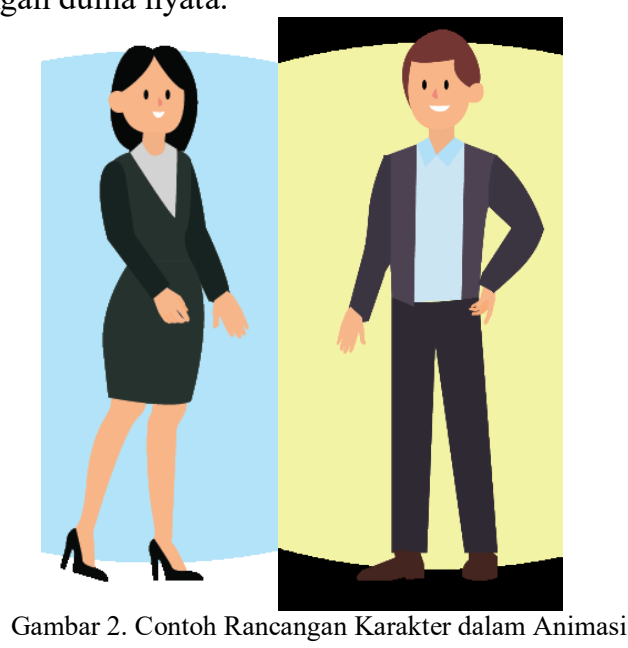

Karakter yang digunakan dalam perancangan animasi adalah jenis kartun. Karakter yang dipilih adalah pegawai atau staff di sebuah kantor yang terdiri dari Resepsionis (wanita), Kepala HRD (wanita), dan calon pelamar pekerjaan (pria). Masingmasing karakter digambarkan dengan berpakaian rapi sebagaimana pegawai kantor dan seorang pelamar kerja sesuai dengan kondisi yang seharusnya, seperti pada Gambar 2.

\subsection{Location and Interface}

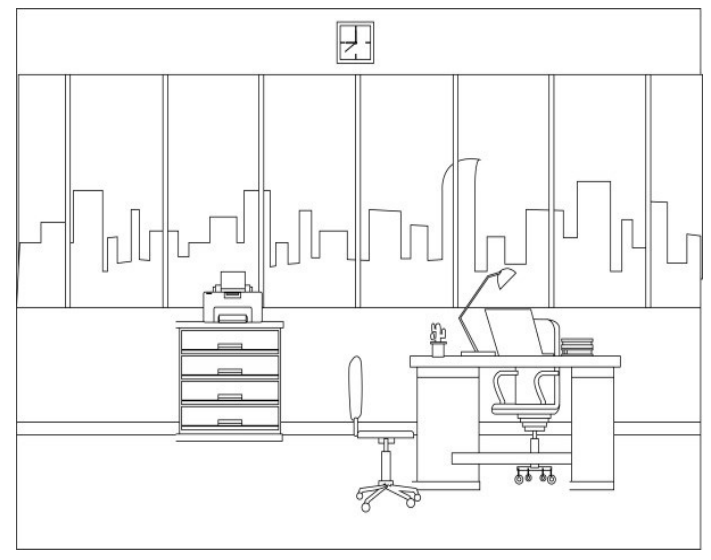

Gambar 3. Contoh Rancangan Lokasi Ruang Kantor

Pada tahap ini ditentukan lokasi, tata letak dan komposisi dalam animasi yang dibuat. Video animasi ditampilkan dalam sebuah layar penuh yang menampilkan suasana ruang kantor seperti pada Gambar 3 dan berbagai karakter yang telah dirancang. 


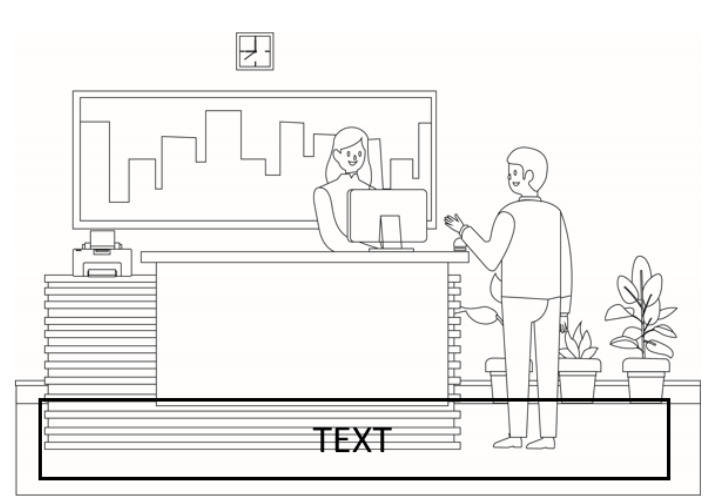

Gambar 4. Tata Letak Kalimat dalam Layar

Selain menggunakan suara (audio) dari animasi, kalimat bahasa Inggris yang dilafalkan oleh karakter setiap karakter dalam dialog tersebut akan ditampilkan di layar untuk membantu pemahaman percakapan yang terjadi. Susunan kalimat dalam bahasa Inggris pada dialog tersebut akan diletakan pada bagian bawah layar dengan tidak mengurangi atau mengganggu tampilan animasi yang ada, seperti terlihat pada Gambar 4.

\subsection{Plotting}

Setelah mendapat gambaran lokasi dan karakter yang telah dirancang, selanjutnya kesemuanya dihubungkan untuk membentuk berbagai jalan cerita dalam sketsa animasi. Penyesuaian terhadap dunia nyata juga dilakukan dalam sajian animasi yang dirancang menjadi beberapa bagian. Penataan lay out setiap obyek karakter beserta properti yang dipakai dalam setiap adegan dilakukan pada semua adegan yang terdiri dari beberapa scene.

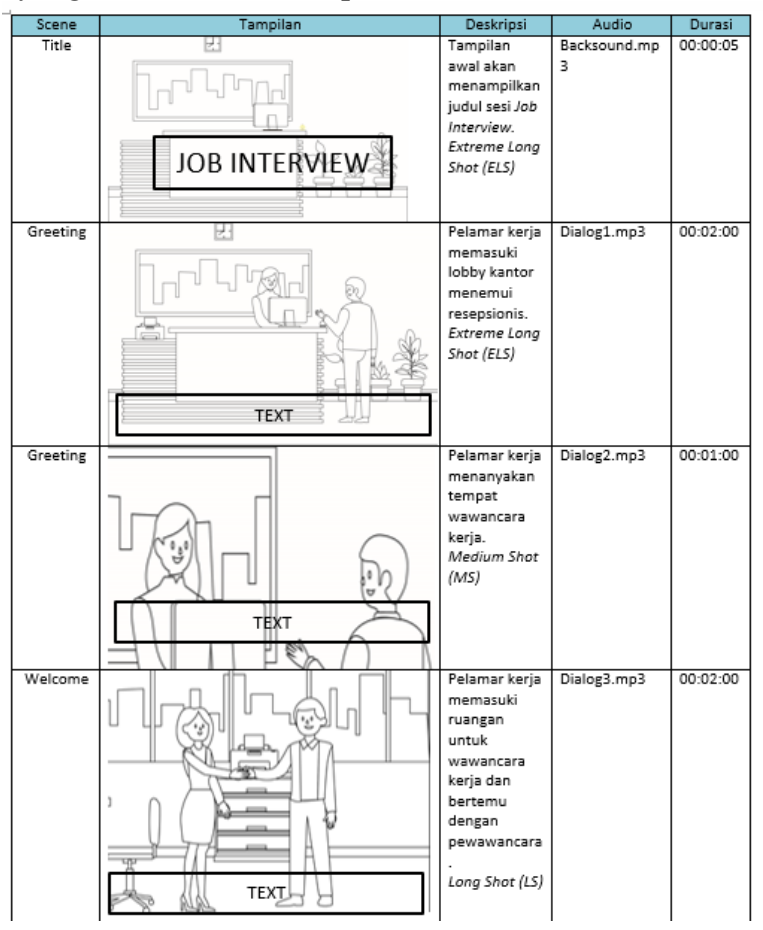

Gambar 5. Storyboard dalam Perancangan Animasi
Storyboard digunakan untuk membantu penyusunan alur cerita dalam animasi sehingga tidak melenceng dari jalan cerita. Contoh storyboard untuk perancangan animasi dalam penelitian ini dapat dilihat pada Gambar 5. Dalam storyboard terdapat keterangan bagian alur cerita, desain tampilan sesuai scene, deskripsi, teknik kamera, audio yang digunakan mengenai percakapan yang terjadi pada setiap scene.

Berdasarkan deskripsi yang telah disusun dalam storyboard selanjutnya dijabarkan dialog pada percakapan sebenarnya. Proses pembuatan skenario sendiri memerlukan keterampilan menulis yang bagus untuk menghasilkan dialog yang bagus dan sesuai. Contoh skenario pada animasi dapat dilihat pada Gambar 6.

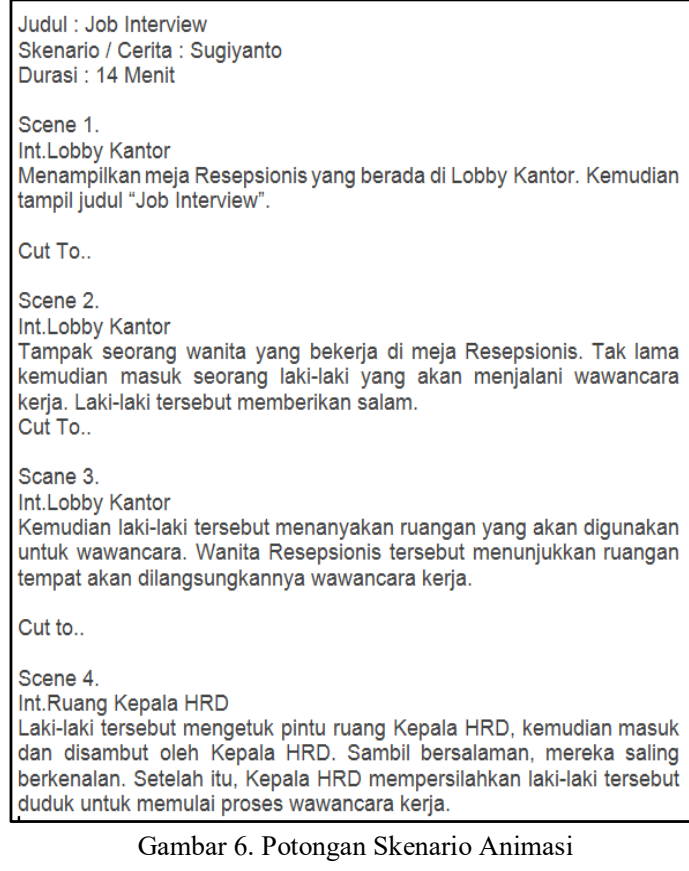

Gambar 6. Potongan Skenario Animasi

\section{HASIL DAN PEMBAHASAN}

Berdasarkan hasil perancangan yang telah dilakukan dari tahap problem definition hingga scripting, rancangan animasi keterampilan berbicara bahasa Inggris telah berhasil dibuat. Selanjutnya pada tahap production and testing dilakukan implementasi animasi sesuai hasil rancangan. Implementasi animasi dilakukan dengan menggabungkan berbagai komponen yang terdiri dari gambar, suara dan teks kalimat bahasa Inggris. Pada penelitian ini telah dikembangkan video animasi bahasa Inggris berjudul Job Interview dengan durasi 1 jam 38 menit. Contoh tampilan dari potongan animasi dapat dilihat pada Gambar 7.

Salah satu tujuan animasi ini untuk melatih keterampilan berbicara sehingga suara yang digunakan harus jelas, keras dan benar pelafalannya untuk melatih aspek fluency, clarity, intonation dan volume. Selain itu, untuk melatih aspek accuracy dan content maka gambar animasi yang dirancang juga 
dilengkapi teks kalimat bahasa Inggris. Contoh dialog yang terjadi saat wawancara kerja seperti yang ditampilkan pada Gambar 8.

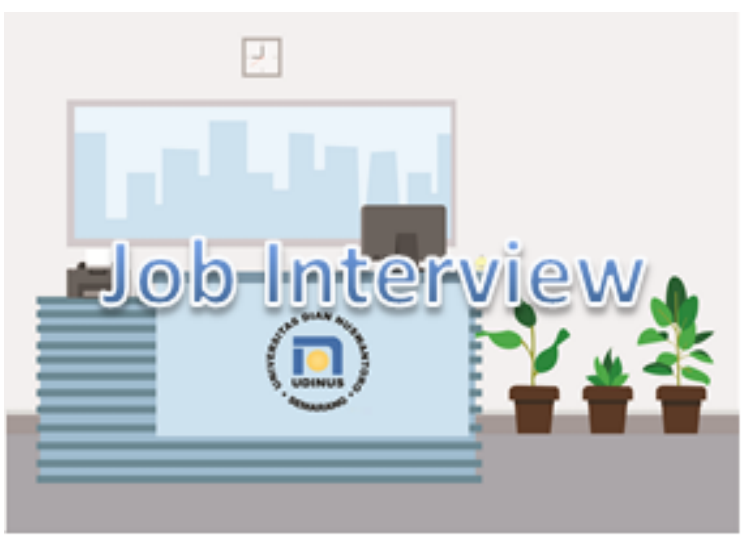

Gambar 7. Contoh Tampilan Awal Animasi

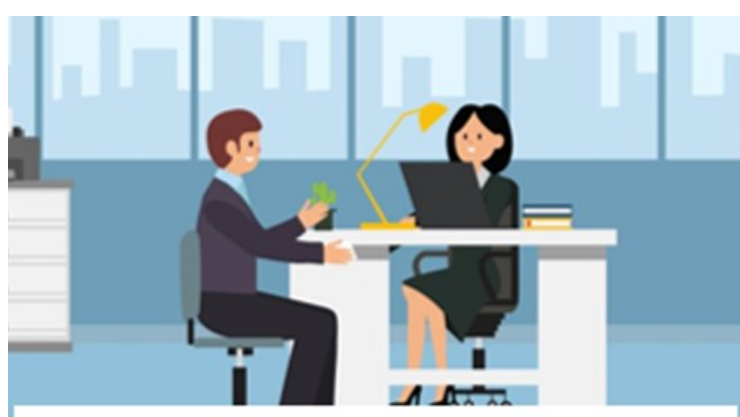

How would you describe your experience there?

Gambar 8. Contoh Percakapan dalam Animasi

Selain aspek seni yang digunakan pada tahap perancangan, pembuatan animasi 2D menggunakan teknologi Adobe Flash dan After Effect. Pada tahap ini dibutuhkan peran animator untuk penggabungan semua bahan hingga menjadi animasi dan siap dipakai. Hasil akhir video animasi dibuat dalam bentuk .mp4 agar mudah digunakan dan didistribusikan.

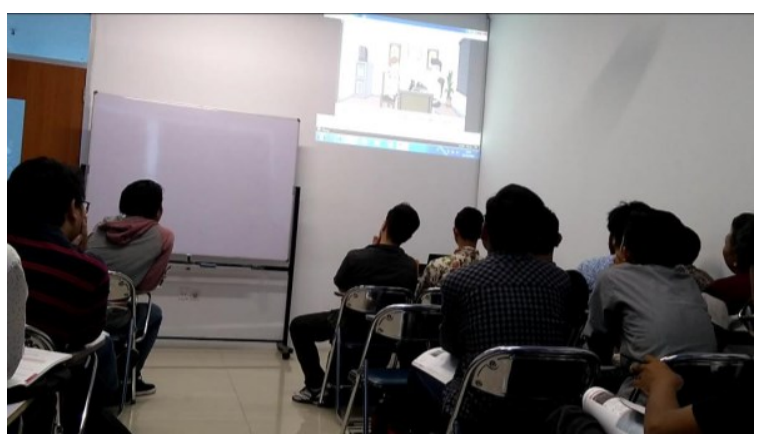

Gambar 9. Pengujian Beta Animasi

Pengujian dilakukan setelah pembuatan animasi yang telah selesai. Metode pengujian yang digunakan untuk animasi yang telah dihasilkan dalam penelitian ini adalah pengujian beta atau lebih dikenal dengan pengujian pengguna. Animasi ditampilkan kepada para mahasiswa yang menjadi target peserta kelas eksperimen seperti terlihat pada Gambar 9.

Hasil pengujian beta berupa penilaian terhadap animasi yang telah dihasilkan dengan memberikan kuesioner tertutup. Kusioner terdiri dari empat pertanyaan terkait aspek gambar, karakter, teks kalimat dan suara, serta satu saran. Pemilihan kuesioner tertutup memudahkan responden sehingga hanya memilih jawaban yang sesuai dengan persepsi masing-masing. Kuesioner diberikan pada dua kelas eksperimen dengan total 68 peserta kelas. Adapun hasil penilaian untuk rata-rata aspek gambar adalah 84, nilai aspek karakter 90 karena menarik, teks kalimat mendapat nilai 88 dan nilai aspek suara 80 . Secara keseluruhan, dari rata-rata penilaian seluruh aspek adalah 85,5 yang menunjukkan bahwa animasi cukup jelas dan menarik. Saran yang telah diberikan responden akan digunakan untuk perbaikan animasi yang telah dibuat.

Selain itu, untuk menilai hasil keterampilan berbicara bahasa Inggris dilakukan penelitian dengan metode eksperimen terhadap peserta kelas. Terdapat empat kelas mahasiswa semester I yang dibagi menjadi dua kelas kontrol dan dua kelas eksperimen. Kedua jenis kelas diberikan materi yang sama akan tetapi pada kelas eksperimen diberikan materi dengan penggunaan media pembelajaran animasi. Pre-test yang sama diberikan pada kedua jenis kelas pada awal penelitian dan di akhir penelitian juga diberikan post-test yang sama untuk kedua jenis kelas.

Penilaian hasil pre-test dan post-test selanjutnya diolah menggunakan SPSS dengan pengujian T-Test dengan df 40 significant (2-tailed) yang menunjukkan nilai signifikan di bawah 0,05 . Hasil tersebut menunjukkan ada perbedaan signifikan pada kelas eksperimen pada sebelum dan sesudah pemanfaatan media animasi untuk pembelajaran Bahasa Inggris. Hasil penelitian eksperimen pada Tabel 1 menunjukkan perbedaan nilai pada kedua kelas. Perolehan nilai speaking setelah post-test pada kelas eksperimen lebih tinggi dibanding kelas kontrol. Hal ini menunjukkan penggunaan media pembelajaran animasi pada kelas eksperimen dapat meningkatkan keterampilan berbicara bahasa Inggris.

\begin{tabular}{ccccc}
\multicolumn{2}{l}{ Tabel 1. Hasil Penelitian Eksperimen } & & \\
\hline Komponen & \multicolumn{2}{c}{ Kelas Kontrol } & \multicolumn{2}{c}{ Kelas Eksperimen } \\
\hline & Pre- & Post- & Pre- & Post- \\
& Test & Test & Test & Test \\
Jumlah Kelas & 2 & 2 & 2 & 2 \\
Nilai Tertinggi & 69 & 79 & 69 & 80 \\
Nilai Terendah & 64 & 68 & 64 & 70 \\
\hline
\end{tabular}

\section{KESIMPULAN}

Pada penelitian ini telah dikembangkan animasi keterampilan berbicara bahasa Inggris menggunakan metode pengembangan Multimedia Development Life Cycle Godfrey dengan tujuh tahapan yang mudah dipahami dan terstruktur. Dari hasil pengujian beta terhadap video animasi rata-rata total penilaian adalah 85,5 yang menunjukkan bahwa hasilnya cukup 
jelas dan menarik. Sedangkan dari hasil penelitian eksperimen menunjukkan hasil peningkatan yang signifikan. Dengan terbiasa membaca dan mendengar kalimat bahasa Inggris melalui animasi, diharapkan masyarakat dapat meningkatkan keterampilan bicara bahasa Inggris.

\section{UCAPAN TERIMA KASIH}

Ucapan terima kasih ditujukan kepada Lembaga Penelitian dan Pengabdian Masyarakat (LPPM) Universitas Dian Nuswantoro yang telah memberikan kesempatan untuk dapat melakukan penelitian.

\section{DAFTAR PUSTAKA}

ARIYATI S. dan MISRIATI T. 2016. Perancangan Animasi Interaktif Pembelajaran Asmaul Husna. Jurnal Teknik Komputer AMIK BSI. Vol. II, No. 1. Februari 2016. 116-121.

BINANTO, I. 2013. Perbandingan Metode Pengembangan Perangkat Lunak Multimedia. Dalam: Prosiding Seminar RiTekTra 2013.

ENGLISH FIRST. 2018. EF EPI - Indeks Kecakapan Bahasa Inggris EF. Tersedia di: <http: https://www.ef.co.id/epi/> [Diakses 12 Januari 2019]

ERYANTI, ARTA U. S., dan MARIA. 2018. Media Pembelajaran Bahasa Inggris Untuk Pengenalan Anggota Tubuh Berbasis Multimedia Interaktif. Journal of Digital Education, Communication and Arts. Vol. 1, No. 1. March 2018. 55-64.

GODFREY, R. 1995. New Wine in Old Bottle: Multimedia Design Methodology. Dalam: Proceeding ASCILITE '95 Australia.

JAEDUN, A. 2011. Metodologi Penelitian Eksperimen. Makalah Dalam Kegiatan In Service I Pelatihan Penulisan Artikel Ilmiah, yang Diselenggarakan LPMP Provinsi Daerah Istimewa Yogyakarta. 20 - 23 Juni 2011.

KING, L.S., ASRORI, H.M. \& REGINA. 2014. Pengembangan Multimedia Pembelajaran Untuk Pemerolehan Belajar Berbicara (Speaking) Di Kelas X Smk Negeri 1 Sengah Temila. Jurnal Pendidikan dan Pembelajaran. Vol. 3, No. 7. Juli 2014.

PUTRI, A.S. 2018. Peringkat Kemampuan Berbahasa Inggris Orang Indonesia Masih Harus Ditingkatkan, [online] Tersedia di < https://www.fimela.com/lifestylerelationship/read/3812134/peringkatkemampuan-berbahasa-inggris-orangindonesia-masih-harus-ditingkatkan> [Diakses 13 Januari 2019]

SOENYOTO, P. 2017. Animasi 2D. Jakarta: Elex Media Komputindo.
ZAIM, M. 2013. Asesmen Otentik: Implementasi dan Permasalahannya dalam Pembelajaran Bahasa Inggris di Sekolah Menengah. Dalam: Proceeding of the International Seminar on Language and Art. 